\title{
Tularemia and plague survey in rodents in an earthquake zone in southeastern Iran
}

\author{
Behzad Pourhossein ${ }^{1,2}$, Saber Esmaeili ${ }^{2,3,4}$, Miklós Gyuranecz ${ }^{5}$, Ehsan Mostafavi ${ }^{2,3}$ \\ ${ }^{1}$ Department of Virology, School of Public Health, Tehran University of Medical Sciences, Tehran; '2Department of Epidemiology, Pasteur \\ Institute of Iran, Tehran; ${ }^{3}$ National Reference Laboratory for Plague, Tularemia and Q Fever, Research Centre for Emerging and Re-emerging \\ Infectious Diseases, Pasteur Institute of Iran, Akanlu, Kabudar Ahang, Hamadan; ${ }^{\circledR}$ Department of Bacteriology, Faculty of Medical Sciences, \\ Tarbiat Modares University, Tehran, Iran; ${ }^{5}$ nstitute for Veterinary Medical Research, Centre for Agricultural Research, Hungarian Academy of \\ Sciences, Budapest, Hungary
}

OBJECTIVES: Earthquakes are one the most common natural disasters that lead to increased mortality and morbidity from transmissible diseases, partially because the rodents displaced by an earthquake can lead to an increased rate of disease transmission. The aim of this study was to evaluate the prevalence of plague and tularemia in rodents in the earthquake zones in southeastern Iran.

METHODS: In April 2013, a research team was dispatched to explore the possible presence of diseases in rodents displaced by a recent earthquake magnitude 7.7 around the cities of Khash and Saravan in Sistan and Baluchestan Province. Rodents were trapped near and in the earthquake zone, in a location where an outbreak of tularemia was reported in 2007 . Rodent serums were tested for a serological survey using an enzyme-linked immunosorbent assay.

RESULTS: In the 13 areas that were studied, nine rodents were caught over a total of 200 trap-days. Fortyeight fleas and 10 ticks were obtained from the rodents. The ticks were from the Hyalomma genus and the fleas were from the Xenopsylla genus. All the trapped rodents were Tatera indica. Serological results were negative for plague, but the serum agglutination test was positive for tularemia in one of the rodents. Tatera indica has never been previously documented to be involved in the transmission of tularemia.

CONCLUSIONS: No evidence of the plague cycle was found in the rodents of the area, but evidence was found of tularemia infection in rodents, as demonstrated by a positive serological test for tularemia in one rodent.

KEY WORDS: Plague, Tularemia, Earthquakes, Iran

\section{INTRODUCTION}

Natural disasters, including floods, earthquakes, and hurricanes, occur every year throughout the world. Outbreaks of infectious diseases after natural disasters have been recorded throu-

Correspondence: Ehsan Mostafavi

Department of Epidemiology, Pasteur Institute of Iran, 69 Pasteur Ave., Tehran 1316943551, Iran

Tel/Fax: +98-21-66496448, E-mail: mostafavi@pasteur.ac.ir

Received: Aug 30, 2015, Accepted: Nov 17, 2015, Published: Nov 17, 2015

This article is available from: http://e-epih.org/

(C) 2015, Korean Society of Epidemiology

(C) This is an open-access article distributed under the terms of the Creative Commons Attribution License (http://creativecommons.org/licenses/by/3.0/), which permits unrestricted use, distribution, and reproduction in any medium, provided the original work is properly cited. ghout history. Examples include an outbreak of plague following an earthquake and fire in the US (1906) [1], a plague outbreak in Maharashtra after an earthquake in India (1993) [2], coccidiosis outbreaks in the US after an earthquake (1994) [3], outbreaks of pneumonia after an earthquake in Japan (1995) [4], an outbreak of pulmonary diseases and gastrointestinal diseases after the Bam earthquake in Iran (2003) [5], an outbreak of malaria after a tsunami in India (2004) [2], and a tularemia outbreak after a flood and earthquake in Turkey (2005) [6].

Earthquakes are one of the most common natural disasters, imposing heavy costs on individuals and governments, and can cause increased mortality and morbidity from infectious diseases [7]. Iran is considered one of the world's 10 most earthquake-prone countries. This means that on average, every five years a severe earthquake, accompanied by financial losses and/ 
or casualties, occurs in Iran [5].After an earthquake, public health is compromised due to limited access to clean water, lack of food and malnutrition, and an increase in direct contact between humans and infected reservoir animals and vectors [8]. Additionally, after an earthquake, people overwhelm shelters. In such situations, outbreaks of vector-borne and zoonotic diseases such as malaria, plague, tularemia, and cutaneous leishmaniasis have been reported. After disasters, it is important to assess the infection status of the intermediate hosts (rodents, mosquitoes, etc.) of the diseases that are prevalent in the region [9-11].

Yersinia pestis is a Gram-negative bacterium that causes plague [12]. This bacterium is a major threat to human health after natural disasters. Plague outbreaks have occurred following earthquakes in San Francisco (1906),Armenia (1988), and India (1994) [13-15].

The intracellular Gram-negative bacterium Francisella tularensis causes tularemia. This bacterium is circulated in wildlife between small mammals and carnivores and their ectoparasites. The bacterium is highly stable in water and soil. In natural disasters where the human ecosystem is affected, such as floods and earthquakes, closer contact inevitability occurs between humans and wildlife. The use of unsafe water due to the lack of usable and appropriate water also increases the risk of this disease [16].

Fleas are the main vector of plague bacteria [13] and ticks are one of the main vectors of tularemia [17]. Plague and tularemia are associated with different pathological symptoms in rodents. Plague leads to splenomegaly, swollen lymph nodes, and swelling and congestion in the liver and spleen, which are significant indications in an autopsy [18,19]. In rodents, an infection with $F$. tularensis can cause symptoms of pyogranulomatous inflammation in the liver and spleen that can lead to mortality within three days [20].

An outbreak of plague was reported in 1906 in the province of Sistan and Baluchestan, around Sistan Lake [21]. In a study conducted in 1973 in Iran, tularemia antibodies were found in one porcupine in this province [22]. A 2011 study conducted in Sistan and Baluchestan Province found tularemia seroprevalence among butchers and slaughterhouse workers [23]. In 2007, an outbreak, first suspected to be plague, occurred in southeastern Iran in Sistan and Baluchestan Province, between the cities of Khash and Saravan (Gosht region), leading to the hospitalization of 34 people and the deaths of eight people. The outbreak was eventually determined to be tularemia [24]. In the same year, an outbreak of plague was reported approximately 100 $\mathrm{km}$ to the east, in the Nimruz Province of Afghanistan [25].

A magnitude 7.7 earthquake occurred on April 20, 2013 in Sistan and Baluchestan Province, in the same region where the outbreak of tularemia occurred in 2007. Due to the possibility of an outbreak of zoonotic disease, a research team from the Pasteur Institute of Iran was dispatched to this area in order to assess the presence of plague and tularemia among rodents in this region.

\section{MATERIALS AND METHODS}

On April 20, 2013, at the request of the Center for Communicable Disease Control at the Ministry of Health, a Pasteur Institute of Iran rapid response team was sent to investigate the presence of plague and tularemia in the areas of Sistan and Baluchestan Province affected by the April 2013 earthquake. The research team was deployed to the area between the cities of Khash and Saravan (the area of the 2007 tularemia outbreak). Rodents were trapped in and around this region (Figure 1). Trapping for rodents was carried out around and inside of the village of Shirkhan in the Khash municipality, in Gosht, and the villages of Abkaokan and Anarak in the Saravan municipality.

The village of Shirkhan is located approximately $55 \mathrm{~km}$ from the center of Khash and is on the border between the metropolitan areas of Saravan and Khash. A limited number of rodent burrows were found in the vicinity of Shirkhan. Abkaokan is only approximately $15 \mathrm{~km}$ from Shirkhan. Rodent burrows were found around and near the village. The village of Anarak is located approximately $10 \mathrm{~km}$ west of Gosht (the epicenter of the earthquake), which is located $70 \mathrm{~km}$ north of Saravan.

Thirteen distinct areas were designated for study. Of these areas, six covered the region of the tularemia outbreak in 2007, with two sampling sites included in the village and four outside the village, in order to monitor the infection status of the rodents. Field observation, rodent trapping, and sampling of the rodents continued from April 20 to April 24, 2013 in these areas (Figure 1).

Wooden live traps with dates as bait were used to trap the rodents. Traps were checked daily and the rodents' ectoparasites were collected on site. Traps were checked early in the morning to avoid overheating the rodents. The rodents were then transferred to the central laboratory of Saravan Health Center for blood sampling and autopsy. After chloroform anesthesia, blood samples were taken directly from the hearts of the trapped rodents and serum was obtained using centrifuges at 3,500 rpm for 10 minutes. Serum samples were stored at $-20^{\circ} \mathrm{C}$.

After blood samples were taken from the animals, the rodents were autopsied and lesions in various organs were assessed. The ectoparasites and rodents were preserved in alcohol and were transferred, along with the serum samples, to the Research Center for Emerging and Re-emerging Infectious Diseases (National Reference Center for Diagnosis and Research on Plague, Tularemia and Q Fever) at the Pasteur Institute of Iran. Fleas 
and rodents were identified according to reference standards [26-28]. Enzyme-linked immunosorbent assay (ELISA) testing was performed on the serum samples to detect immunoglobulin $\mathrm{G}$ (IgG) antibodies against Y. pestis according to the protocol of the World Health Organization Reference Laboratory at the Pasteur Institute of Madagascar [29]. Additionally, serological testing for tularemia was performed on rodent serum sam- ples using the agglutination method [30].

\section{RESULTS}

Nine rodents were caught over a total of 200 trap-days in the 13 surveyed areas, and 48 fleas and 10 ticks were isolated. All

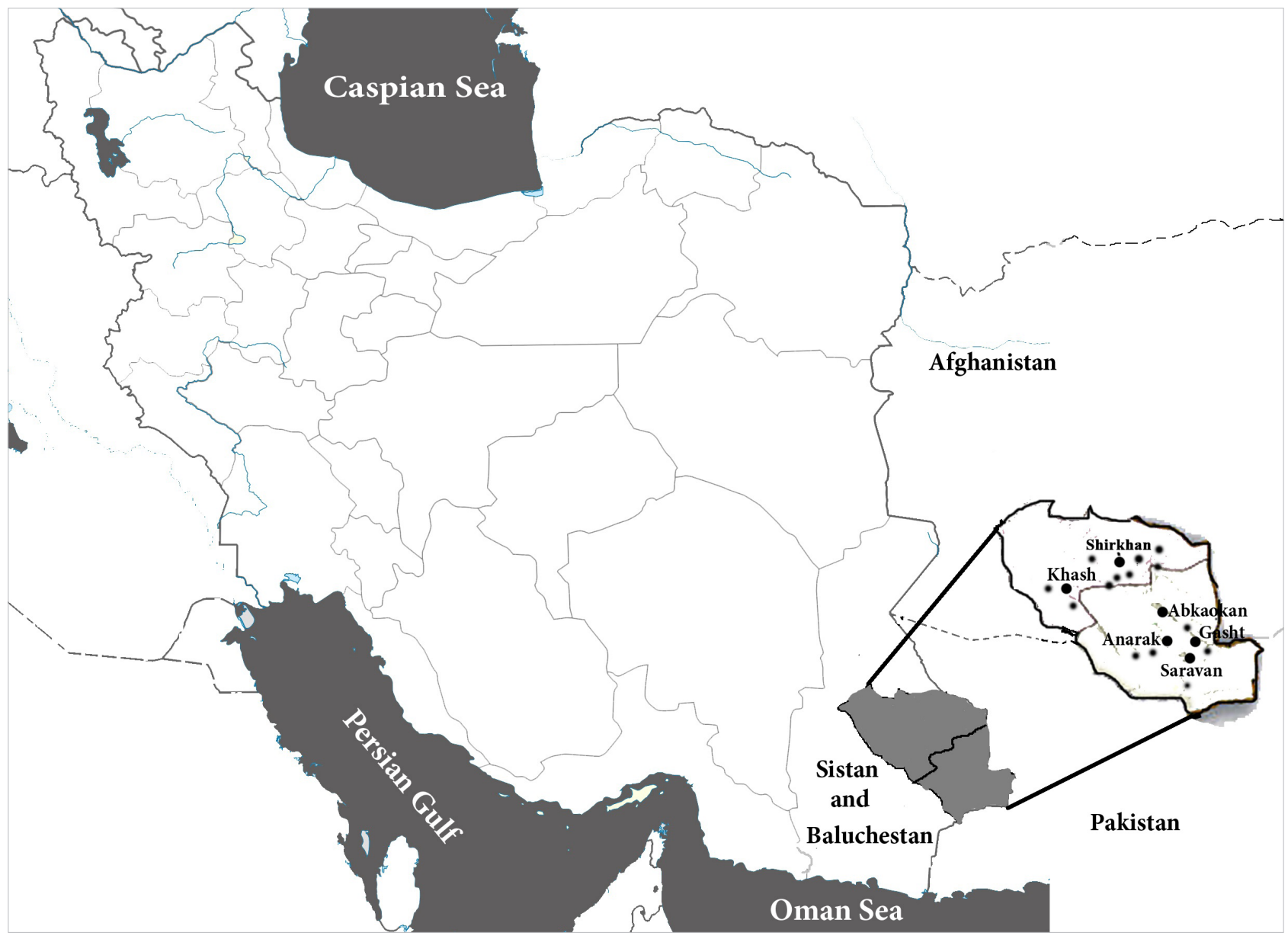

Figure 1. The area of study and sampling locations in Khash and Saravan in Sistan and Baluchestan Province, southeastern Iran.

Table 1. The number of rodents and ectoparasites collected in Sistan and Baluchestan Province after the 2013 earthquake

\begin{tabular}{llccccc}
\hline Name of sampling area & Municipality & $\begin{array}{c}\text { No. of locations } \\
\text { sampled }\end{array}$ & Trap-days & $\begin{array}{c}\text { Type of trapped } \\
\text { rodents (n) }\end{array}$ & No. of ticks & No. of fleas \\
\hline Shirkhan (village) & Khash & 6 & 62 & 6 & - & -2 \\
Abkaokan (village) & Saravan & 1 & 15 & 1 & - & - \\
Waste disposal sites & Gosht & 2 & 28 & 1 & - & - \\
Anarak (village) & Saravan & 2 & 75 & $2^{2}$ & 10 & 20 \\
Kamal Abad (village) & Saravan & 2 & 20 & 9 & 10 & 48 \\
Total & & 13 & 200 & & \\
\hline
\end{tabular}

${ }^{1}$ Operator error resulted in the animal escaping.

${ }^{2}$ One of the animals trapped was a porcupine. 
ticks were from the Ixodidae family, Hyalomma genus and all fleas were Xenopsylla spp.

On average, five fleas and one tick were visible on each rodent. All rodents were Tatera indica. Around the village of Anarak, in an area of approximately $10 \mathrm{~km}^{2}$, inactive nests were found, indicating a mass migration of the rodents. This may have been due to a flood and the resultant presence of transient water in riverbeds.

In the village of Kamal Abad, a porcupine (Erinaceidae) was trapped, five ticks were isolated from its surface and after blood sampling, it was sent for an autopsy to inspect its internal organs (Table 1). Pathological lesions were not observed in any of the trapped animals.

ELISA results for anti-plague antibodies (IgG) for all samples were negative. Serological testing using the agglutination method for assessing tularemia infection was positive, with serum titers of $1 / 80$ in one rodent trapped in the Saravan municipality (Abkaokan village).

\section{DISCUSSION}

In this study, serological tests found no cases of plague infection among the trapped rodents and porcupine, while serological testing was positive for tularemia in one rodent. The ticks and fleas that were found on the body of the trapped rodents in this study are suitable vectors for the transmission of diseases such as plague, tularemia, murine typhus, and viral diseases such as Crimean-Congo hemorrhagic fever [31-33].

Several genera of rodents, including Apodemus and Rattus, can be reservoirs of tularemia [34], but the most notable finding of this study was a serologically positive Indian gerbil (Tatera indica). The Indian gerbil is the most common rodent in Sistan and Baluchestan Province [22], but tularemia infection has never before been reported in this type of rodent, either in the region or in the rest of the world. It is therefore important to carry out further research on Tatera indica in order to establish their possible role in the transmission of tularemia.

It can be stated that the risk of tularemia transmission increased in this region after the 2013 earthquake, in light of the previous tularemia outbreak in 2007 (in Saravan and Khash in Sistan and Baluchestan Province) [24], the tularemia-positive rodent found in this study, and the changing living conditions of the human residents affected by the earthquake, who moved from homes to open spaces, resulting in close contact between humans and rodents and the consumption of unsafe water due to the lack of appropriate water sources.

No cases of human tularemia were reported following the April 2013 earthquake in this region, in contrast to the 1999 earthquake in Turkey, after which several human cases of tula- remia were reported [6].

It is common for residents to fear that a natural disaster will repeat itself, especially after earthquakes. This fear leads residents to congregate outside their homes in areas without proper sanitary facilities, which can cause direct and indirect contact with rodents, increasing the likelihood of exposure to diseases transmitted by rodents [35].

As is the case for the present study, most epidemiological studies in the areas affected by natural disasters are cross-sectional surveys, meaning that they cannot show a causal link between the occurrence of disease and the disasters. Economic recessions generally occur after disasters, and resources and facilities in the affected area may be scarce. These conditions reduce the level of health, and the post-disaster period is a time when outbreaks are known to begin [36,37].

One of the limitations of this study was the lack of access to supplementary serological tests for tularemia. The agglutination test is the primary screening test for the diagnosis of tularemia, but the definitive test to detect this disease is a culture, immunofluorescence antibody, or western blot test. The agglutination test may have false-positive results because it is capable of crossreacting with several other infectious agents, such as Brucella spp. [38]. It would have been preferable for the positive sample be rechecked using a definitive test [39] but we had no access to such tests. In future studies of this type, it is recommended to use definitive tests to confirm the results of an initial screening.

Another limitation of this study was the low number of samples tested. During the field visit, few active rodent nests were found, whereas abandoned nests were abundant, indicating a large rodent migration due to drought, flooding, or unknown reasons over the previous years. Flooding is one of the main reasons that rodents migrate [40]. Sistan and Baluchestan Province has a hot and dry climate and steppe vegetation [40]. The earthquake in 2013 occurred during the rainy season and the team was therefore not able to trap a large number of rodents. In similar studies in the future, the research team should spend more time in the region for sampling, and sampling should be repeated two to three months after the natural disaster.

Border control in this area, with respect to the health conditions of travelers, should be considered by the relevant authorities. However, due to the presence of potential reservoirs and vectors of plague and tularemia in this region, continuous surveys are necessary to monitor these infectious diseases.

Due to the outbreak of plague in 2007 in Afghanistan and the presence of human and animal traffic between Iran and Afghanistan over the long border between the two countries, as well as the report of an outbreak of tularemia in that year (around Khash and Saravan), the Center for Communicable Disease Control should be made fully aware of endemic diseases and outbreaks in Afghanistan. 
In light of the negative results for plague in this study, the positive serological result for tularemia in a rodent, and the presence of potential hosts and vectors for both diseases in this area, similar studies at other times should also be considered, and health officials, physicians, and healthcare providers need to be more sensitive to these diseases. Additionally, monitoring the movement of people living in this region, which is divided between two countries (Iran and Afghanistan), should be performed with greater precision.

\section{ACKNOWLEDGEMENTS}

We are thankful to the personnel of the Khash and Saravan Health Network and the Zahedan University of Medical Sciences, who worked closely with us on this study. We would also like to thank the staff of the Center for Communicable Diseases Control, who played a role in conceptualizing and coordinating this study, and Mr. Hamed Hanifi, a staff member of the Pasteur Institute of Iran, who helped us in the sampling process of this study. We appreciate the financial support of the Pasteur Institute of Iran and the Center for Communicable Diseases Control in the Iranian Ministry of Health and Medical Education (grant no. 582). Parts of the study were supported by the Lendület (Momentum) program (LP 2012-22) of the Hungarian Academy of Sciences.

\section{CONFLICT OF INTEREST}

The authors have no conflicts of interest to declare for this study.

\section{ORCID}

Behzad Pourhossein http://orcid.org/0000-0002-4263-0612

Saber Esmaeili http://orcid.org/0000-0003-1920-1737

Ehsan Mostafavi http://orcid.org/0000-0002-1997-517X

\section{REFERENCES}

1. Aghababian RV, Teuscher J. Infectious diseases following major disasters. Ann Emerg Med 1992;21:362-367.

2. Krishnamoorthy K, Jambulingam P, Natarajan R, Shriram AN, Das PK, Sehgal SC. Altered environment and risk of malaria outbreak in South Andaman, Andaman \& Nicobar Islands, India affected by tsunami disaster. Malar J 2005;4:32.

3. Schneider E, Hajjeh RA, Spiegel RA, Jibson RW, Harp EL, Marshall GA, et al. A coccidioidomycosis outbreak following the Northridge, Calif, earthquake. JAMA 1997;277:904-908.
4. Matsuoka T, Yoshioka T, Oda J, Tanaka H, Kuwagata Y, Sugimoto H, et al. The impact of a catastrophic earthquake on morbidity rates for various illnesses. Public Health 2000;114:249-253.

5. Jafari NJ, Radfar MH, Ghofrani H. Incidence of infectious diseases one month after the bam earthquake (2004). J Med Sci 2007;7:597602.

6. Karadenizli A, Gurcan S, Kolayli F, Vahaboglu H. Outbreak of tularaemia in Golcuk, Turkey in 2005: report of 5 cases and an overview of the literature from Turkey. Scand J Infect Dis 2005;37:712716.

7. Noji EK. Natural disasters. Crit Care Clin 1991;7:271-292.

8. Connolly MA, Gayer M, Ryan MJ, Salama P, Spiegel P, Heymann DL. Communicable diseases in complex emergencies: impact and challenges. Lancet 2004;364:1974-1983.

9. Ivers LC, Ryan ET. Infectious diseases of severe weather-related and flood-related natural disasters. Curr Opin Infect Dis 2006;19:408-414.

10. Kouadio IK, Aljunid S, Kamigaki T, Hammad K, Oshitani H. Infectious diseases following natural disasters: prevention and control measures. Expert Rev Anti Infect Ther 2012;10:95-104.

11. Wei L, Wang X, Wang C, He H. A survey of ectoparasites from wild rodents andAnourosorex squamipes in Sichuan Province, Southwest China. J Ecol Nat Environ 2010;2:160-166.

12. Perry RD, Fetherston JD. Yersinia pestis--etiologic agent of plague. Clin Microbiol Rev 1997;10:35-66.

13. Titball RW, Leary SE. Plague. Br Med Bull 1998;54:625-633.

14. Tsereteli D, Bakanidze L, Velijanashvili I, Beridze L, Manrikyan M, Shakhikyan M, et al. Plague in southern Caucasus. Antibiot Monit 2002;18:14-16.

15. Ligon BL. Plague: a review of its history and potential as a biological weapon. Semin Pediatr Infect Dis 2006;17:161-170.

16. Furusawa T, Maki N, Suzuki S. Bacterial contamination of drinking water and nutritional quality of diet in the areas of the western Solomon Islands devastated by the April 2, 2007. Trop Med Health 2008; 36:65-74.

17. Baltazard M, Karimi Y, Eftekhari M, Chamsa M, Mollaret HH. The interepizootic preservation of plague in an inveterate focus. Working hypotheses. Bull Soc Pathol Exot Filiales 1963;56:1230-1245 (French).

18. Swearengen JR. Biodefense: research methodology and animal models. Boca Raton: CRC Press; 2012, p. 113.

19. Wilkins BS, Lucas SB. Lymph node pathology in infectious diseases. Diagn Histopathol (Oxf) 2013;19:89-98.

20. Moe JB, Canonico PG, Stookey JL, Powanda MC, Cockerell GL. Pathogenesis of tularemia in immune and nonimmune rats. Am J Vet Res 1975;36:1505-1510.

21. Floor WM. Public health in Qajar Iran. Washington, DC: Mage Publishers; 2004, p. 21-24.

22. Arata A, Chamsa H, Farhang-Azad A, Mescerjakova O, Neronov V, Saidi S. First detection of tularaemia in domestic and wild mammals in Iran. Bull World Health Organ 1973;49:597-603.

23. Esmaeili S, Esfandiari B, Maurin M, Gouya MM, Shirzadi MR, Amiri FB, et al. Serological survey of tularemia among butchers and slaughterhouse workers in Iran. Trans R Soc Trop Med Hyg 2014;108: 516-518.

24. Fars News Agency. Tularemia disease has been controlled in Khash [cited 2007 Apr 21]. Available from: http://www.farsnews.com/printable.php?nn=8602010298 (Persian).

25. Leslie T, Whitehouse CA, Yingst S, Baldwin C, Kakar F, Mofleh J, et al. Outbreak of gastroenteritis caused by Yersinia pestis in Afghanistan. Epidemiol Infect 2011;139:728-735.

26. Biondi M, D'Alessandro P. Afrotropical flea beetle genera: a key to their identification, updated catalogue and biogeographical analysis 
(Coleoptera, Chrysomelidae, Galerucinae, Alticini). Zookeys 2012; 253:1-158.

27. Lloyd H. Mites and ticks of domestic animals. An identification guide and information source. Vet Dermatol 2004;15:266.

28. Vaughan TA. Ryan JM, Czaplewski NJ. Mammalogy. 5th ed. Sudbury: Jones \& Bartlett Publishers; 2011, p. 477-479.

29. World Health Organization. Interregional meeting on prevention and control of plague; 2008 [cited 2015 Dec 20]. Available from: http:// www.who.int/csr/resources/publications/WHO_HSE_EPR_2008 3w.pdf.

30. Gyuranecz M, Rigó K, Dán A, Földvári G, Makrai L, Dénes B, et al. Investigation of the ecology of Francisella tularensis during an interepizootic period. Vector Borne Zoonotic Dis 2011;11:1031-1035.

31. Bitam I, Dittmar K, Parola P, Whiting MF, Raoult D. Fleas and fleaborne diseases. Int J Infect Dis 2010;14:e667-e676.

32. Gubler DJ, Reiter P, Ebi KL, Yap W, Nasci R, Patz JA. Climate variability and change in the United States: potential impacts on vectorand rodent-borne diseases. Environ Health Perspect 2001;109 Suppl 2:223-233.

33. Esamaeili S, Azadmanesh K, Naddaf SR, Rajerison M, Carniel E, Mostafavi E. Serologic survey of plague in animals, Western Iran. Emerg Infect Dis 2013;19:1549-1551.
34. Zhang F, Liu W, Chu MC, He J, Duan Q, Wu XM, et al. Francisella tularensis in rodents, China. Emerg Infect Dis 2006;12:994-996.

35. Lechat MF. The epidemiology of health effects of disasters. Epidemiol Rev 1990;12:192-198.

36. Roorda J, van Stiphout WA, Huijsman-Rubingh RR. Post-disaster health effects: strategies for investigation and data collection. Experiences from the Enschede firework disaster. J Epidemiol Community Health 2004;58:982-987.

37. Behan KA, Klein GC. Reduction of Brucella species and Francisella tularensis cross-reacting agglutinins by dithiothreitol. J Clin Microbiol 1982;16:756-757.

38. Grunow R, Splettstoesser W, McDonald S, Otterbein C, O’Brien T, Morgan C, et al. Detection of Francisella tularensis in biological specimens using a capture enzyme-linked immunosorbent assay, an immunochromatographic handheld assay, and a PCR. Clin Diagn Lab Immunol 2000;7:86-90.

39. Jacob J. The response of small mammal populations to flooding. Mamm Biol 2003;68:102-111.

40. Lashkaripour GR. An investigation of groundwater condition by geoelectrical resistivity method: a case study in Korin aquifer, southeast Iran. J Spat Hydrol 2003;3:1-5. 